\title{
The Crab-eating Fox (Cerdocyon thous) as a secondary seed disperser of Eugenia umbelliflora (Myrtaceae) in a Restinga forest of southeastern Brazil
}

\author{
Eliana Cazetta ${ }^{1,2,3}$ \& Mauro Galetti ${ }^{1}$ \\ ${ }^{1}$ Grupo de Fenologia e Dispersão de Sementes, Laboratório de Biologia da Conservação, \\ Departamento de Ecologia, Universidade Estadual Paulista - UNESP, \\ CP 199, CEP 13506-900, Rio Claro, SP, Brazil \\ ${ }^{2}$ Departamento de Ciências Biológicas, Universidade Estadual de Santa Cruz - UESC, \\ Rod. Ilhéus-Itabuna, Km 16, CEP 45662-000, Ilhéus, BA, Brazil \\ ${ }^{3}$ Corresponding author: Eliana Cazetta, e-mail: eliana.cazetta@gmail.com
}

CAZETTA, E. \& GALETTI, M. The Crab-eating Fox (Cerdocyon thous) as a secondary seed disperser of Eugenia umbelliflora (Myrtaceae) in a Restinga forest of southeastern Brazil. Biota Neotrop., 9(2): http:// www.biotaneotropica.org.br/v9n2/en/abstract?short-communication+bn02509022009.

\begin{abstract}
The crab-eating fox (Cerdocyon thous) exhibits a very generalist habit and fruits compose a large proportion of its diet. However, few studies evaluated the importance of this animal as seed disperser. In the Restinga forest, in the Atlantic forest of Brazil, C. thous consumes fruits of Eugenia umbelliflora, a Myrtaceae species, which is dispersed chiefly by birds. This study evaluated the effects of gut transit on seed germination, and size selection of E. umbelliflora fruits by the crab-eating fox. We did not find differences on germination rates between seeds dispersed by foxes and control ones, but seeds dispersed by foxes germinated faster, which may be important for plant recruitment. Seeds consumed by $C$. thous were smaller than those available on the ground, indicating selection for small fruits. Regardless of the selection of small fruits, $C$. thous appears to be an important secondary disperser of E. umbelliflora, distributing large quantities of viable seeds of this Myrtaceae in the Restinga forest.

Keywords: Atlantic Forest, carnivores, frugivory, fruit choice, seed dispersal.
\end{abstract}

CAZETTA, E. \& GALETTI, M. O chachorro do mato (Cerdocyon thous) como dispersor secundário de Eugenia umbelliflora (Myrtaceae) em uma floresta de Restinga no sudeste do Brasil. Biota Neotrop., 9(2): http://www.biotaneotropica.org.br/v9n2/pt/abstract?short-communication+bn02509022009.

Resumo: O cachorro do mato (Cerdocyon thous) tem um hábito bastante generalista e frutos compõem uma grande proporção de sua dieta. No entanto, poucos estudos avaliaram a importância deste animal como dispersor de sementes. Na floresta de restinga da Mata Atlântica brasileira C. thous consome frutos de Eugenia umbelliflora, uma espécie de Myrtaceae, que é dispersa principalmente por aves. Este estudo avaliou o efeito da passagem das sementes pelo tubo digestivo na germinação das sementes e a seleção de tamanho de frutos de E. umbelliflora pelo cachorro do mato. Não houve diferença nas taxas de germinação entre as sementes dispersas pelo cachorro do mato e as sementes controle, mas as sementes dispersas pelo cachorro germinaram mais rápido, o que pode ser importante para o recrutamento das plantas. As sementes consumidas pelo cachorro do mato foram menores do que as sementes disponíveis no solo, indicando seleção por frutos menores. Apesar de selecionarem frutos menores, o cachorro do mato parece ser um importante dispersor secundário de E. umbelliflora, distribuindo grandes quantidades de sementes viáveis desta espécie de Myrtaceae na restinga.

Palavras-chave: carnívoros, dispersão de sementes, escolha de frutos, frugivoria, Mata Atlântica. 


\section{Introduction}

Some species of carnivores commonly consume large amounts of fleshy fruits and usually defecate undamaged seeds (Herrera 1989, Willson 1993). Consequently, these animals can play an important role in seed dispersal for many plants (Willson 1993, Otani 2002). Carnivores generally have larger home ranges than herbivores with similar body size (Lindstedt et al. 1986), which leads to longer travel distances and, consequently, to farther seed dispersal (Otani 2002).

The crab-eating fox (Cerdocyon thous Linnaeus) is a medium (4 to $7 \mathrm{~kg}$ ), nocturnal carnivore that is found throughout most of South America (Colombia, Venezuela, Guyana, Suriname, south-eastern Bolivia, Paraguay, Uruguay, north-eastern Argentina, and almost all of Brazil, with the exception of the Amazon basin) (Berta 1987, Medel \& Jaksic 1988). Cerdocyon thous exhibits a generalist and opportunistic diet, feeding on fruits and insects in the rainy season and on small vertebrates during the dry season (Brady 1979, Bisbal \& Ojasti 1980, Motta Jr. et al. 1994, Dalponte 1997, Jácomo et al. 2004), in addition to consuming fruits of cultivated species (CoimbraFilho 1996, Facure \& Monteiro-Filho 1996). In studies of $C$. thous diet, the proportion of fruits consumed is generally high (Facure \& Monteiro-Filho 1996, Facure \& Giaretta 1996, Jácomo et al. 2004). Gatti et al. (2006) found that fruits were the main food item consumed by the crab-eating fox, accounting for $97 \%$ of the diet. Nevertheless, most studies reflect only $C$. thous diet, so additional information is needed on the role of this species as seed disperser.

In a Restinga forest of Ilha do Cardoso, in São Paulo state, Brazil, the fruits of Eugenia umbelliflora O. Berg (Myrtaceae) are primarily consumed by many bird species (Côrtes et al. 2009). However, a previous study on E. umbelliflora seed dispersal showed that only $30 \%$ of the fruits handled by birds were successfully removed (Côrtes et al. 2009). The inefficient dispersal events are due to the behavior of birds from Thaupidae and Parulidae families that presented high frequency visits but were unable to swallow the entire fruit and just pecked pulp pieces, dropping seeds beneath the parent tree or dropping the entire fruit (Côrtes et al. 2009). These fruits fall to the ground and are highly consumed by the crab-eating fox (Cerdocyon thous) and preyed upon by crabs. Therefore, the goal of this study was to evaluate the role of $C$. thous as seed disperser of Eugenia umbelliflora. We were interested in determine the effects of gut transit on germination and size selection of Eugenia umbelliflora fruits by the crab-eating fox. The following questions were addressed: I) Does the crab-eating fox act as a legitimate seed disperser for Eugenia umbelliflora? In other words, do the seeds passing through the animal's digestive tract have higher germination rates than control ones? and II) Does the crabeating fox select the size of Eugenia umbelliflora fruits?

\section{Material and Methods}

\section{Study area}

Fieldwork was carried out on Ilha do Cardoso, a land-bridge subtropical island, in São Paulo state, southeast, Brazil (25 05' S and $47^{\circ} 53^{\prime} \mathrm{W}$ ). Ilha do Cardoso is a 15,100 ha protected island encompassing several types of Atlantic rainforest, including: mangroves, dune vegetation, restinga forest, lowland tropical rainforest and highland tropical rainforest (Noffs \& Baptista Noffs 1982). The present study was conducted in the transition between scrub vegetation and restinga forest (sandy forest), which is characterized by an open canopy that can reach 4-5 m and where Eugenia umbelliflora occurs in high density (Bernardi et al. 2005). Eugenia umbelliflora is a small tree (4-7 $\mathrm{m}$ height) that grows in low elevations under ocean influence in the eastern coast of Brazil. Flowering is annual and occurs from March to May, and fruiting begins in June and extends to October (Staggemeier et al. 2007). Fruits are berries that are red when unripe and purple when ripe, containing one to three seeds (Figure 1a, b). E. umbelliflora fruits are intensively consumed by 17 bird species as well as mammals (Côrtes et al. 2009), such as the crab-eating fox Cerdocyon thous. Generally observed in pairs, this carnivore travels over large areas and the mean home range of the species on the island is 172 ha (Oliveira 2006).

\section{Methods}

Nineteen C. thous scats were collected in October 2003. We selected only faecal samples that contained E. umbelliflora seeds (Figure 2), which presented an average of $39 \pm 18$ (mean \pm sd) seeds per defecation. The scats were washed and separated in the laboratory, and the diameter and length of the seeds were measured. We also collected and measured fruits dropped beneath the canopy ( $\mathrm{N}=253)$ from 12 individuals of Eugenia umbelliflora. We sampled these E. umbelliflora individuals and the scats within an area of $1.1 \mathrm{~km} \times 30 \mathrm{~m}$ in the transition between dune and restinga vegetation.
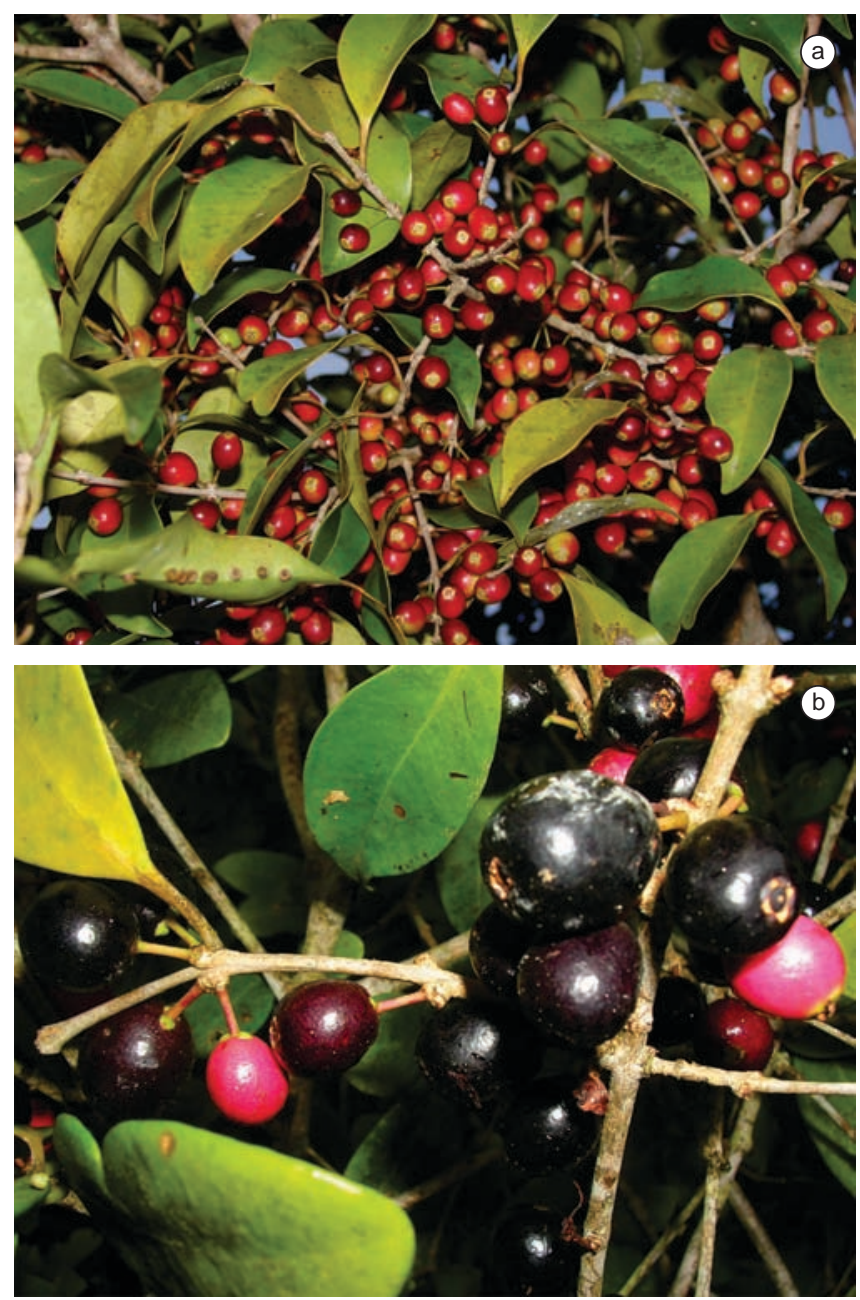

Figure 1. Eugenia umbelliflora a) immature and b) ripe fruits. Photo: a) André C. Guaraldo and b) Eliana Cazetta.

Figura 1. Frutos a) imaturos e b) maduros de Eugenia umbelliflora. Foto: a) André C. Guaraldo e b) Eliana Cazetta. 


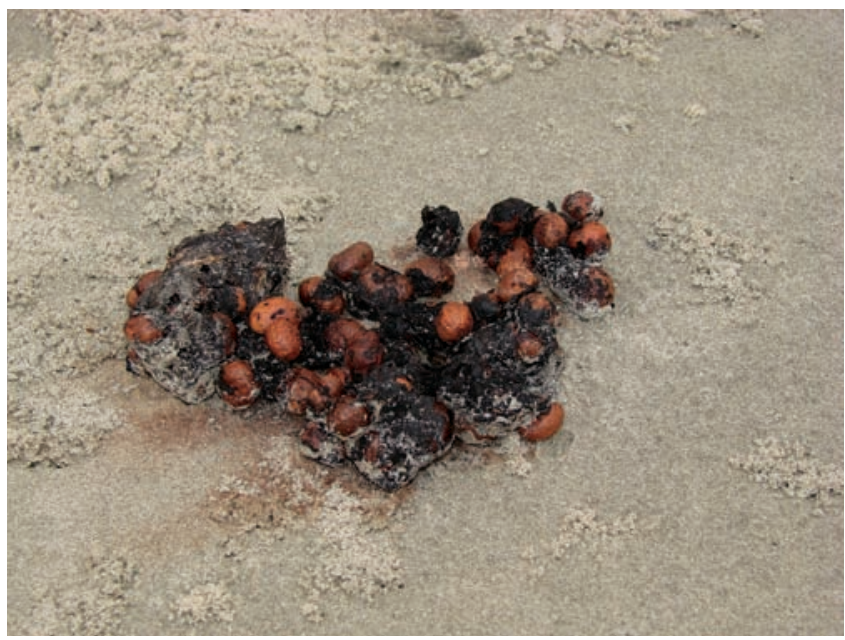

Figure 2. Cerdocyon thous scats containing Eugenia umbelliflora (Myrtaceae) seeds in Ilha do Cardoso, Atlantic rainforest, Brazil. Photo: André C. Guaraldo.

Figura 2. Fezes de Cerdocyoun thous com sementes de Eugenia umbelliflora na Ilha do Cardoso, Floresta Atlântica, Brasil. Foto: André C. Guaraldo.

Germination tests were conducted on 50 Eugenia umbelliflora seeds collected from the scats compared to 120 intact seeds taken directly from different individual trees (control). Seeds were placed in Petri dishes, daily washed, and checked each two weeks for a period of 75 days. The differences in germination rates between treatments were analysed by a chi-square test. Seed survival between treatments was compared using Cox Regression survival analysis. Survival analysis is used when the response variable is a time period until an event occurs. Seed germination was considered the event of interest.

\section{Results}

The mean diameter of E. umbelliflora fruits was $1.07 \pm 0.12 \mathrm{~cm}$ $(\mathrm{N}=253)$, and the mean length was $1.36 \pm 0.18 \mathrm{~cm}(\mathrm{~N}=253)$. The seeds of E. umbelliflora had a mean diameter of $0.93 \pm 0.12 \mathrm{~cm}$ $(\mathrm{N}=253)$ and mean length of $1.21 \pm 0.16 \mathrm{~cm}(\mathrm{~N}=253)$. We found a significant variation between fruit size (diameter $-\mathrm{F}=14.07 \mathrm{df}=10$, $\mathrm{P}<0.0001$, length $-\mathrm{F}=14.67, \mathrm{df}=10, \mathrm{P}<0.0001)$ and seed size (diameter: $\mathrm{F}=11.53, \mathrm{df}=10, \mathrm{P}<0.0001$, length: $\mathrm{F}=16.13, \mathrm{df}=$ $10, \mathrm{P}<0.0001)$ among the 12 individuals of E. umbelliflora. Fruit diameter was highly correlated with seed diameter $\left(\mathrm{R}^{2}=0.61, \mathrm{df}=\right.$ $1320, \mathrm{P}<0.0001)$, and fruit length was also correlated with seed length $\left(\mathrm{R}^{2}=0.71, \mathrm{df}=1320, \mathrm{P}<0.0001\right)$. The seeds dispersed by the crab-eating fox had a mean diameter of $0.88 \pm 0.15 \mathrm{~cm}(\mathrm{~N}=756)$ and a mean length of $1.13 \pm 0.18 \mathrm{~cm}(\mathrm{~N}=756)$. These seeds were smaller than those collected directly in the trees $(\mathrm{t}=-5.15 \mathrm{P}<0.0001)$. Nevertheless, differences in seed diameter were small, lower than $6.4 \%$. The coefficient of variance between control seed size and fox-dispersed seeds were similarly high (12.9 an 17\%, respectively).

The percentage of germination was slightly higher for seeds found in the scats $(56 \%)$ than control seeds $(43.9 \%)$, although this difference was not significant $\left(\chi^{2}=0.69, \mathrm{P}=0.40\right)$. The survival rate was different between the two treatments evaluated. Seeds collected from the scats have higher germination rates than control ones (Cox Regression, $\chi^{2}=4.08, \mathrm{df}=1, \mathrm{P}=0,04$ ) (Figure 3).

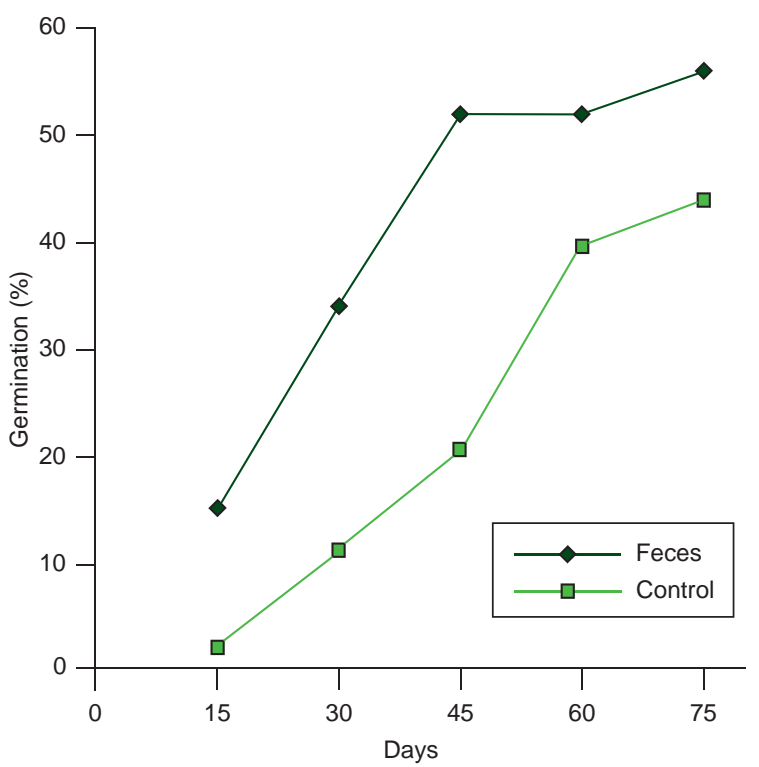

Figure 3. Germination time of Eugenia umbelliflora seeds found in Cerdocyon thous scats compared to control seeds.

Figura 3. Tempo de germinação das sementes de Eugenia umbelliflora encontrada nas fezes de Cerdocyoun thous comparada com sementes controle.

\section{Discussion}

Crab-eating fox dispersed seeds are viable and germinate faster than control seeds. This indicates that the crab-eating fox is a legitimate disperser, and that the consumption of E. umbelliflora fruits by the fox is beneficial for the dispersal of the seeds. Bustamante et al. (1992) found similar results in a study of seed germination consumed by foxes (Dusicyon culpaeus) in Chile. The red fox (Vulpes vulpes) also favours germination and seedling survival of the Mediterranean Hackberry (Traba et al. 2006). In the Monte Desert in Argentina, Campos \& Ojeda (1997) found that foxes (Pseudalopex griseus) were also legitimate dispersers, although they did not increase the proportion of seeds that germinated.

Eugenia umbelliflora seeds dispersed by the crab-eating fox are smaller than those available on the ground, probably because foxes select smaller fruits by rejecting or spitting out larger ones. Several studies about fruit selection by birds have found evidence for selection towards small fruits (Wheelwright 1985, Rey et al. 1997, Côrtes et al. 2009), but only recently the same behavior was documented for another species of canid (Vulpes vulpes) (Traba et al. 2006). Although differences between control and crab-eating fox seeds are small, fruit discrimination and dispersal of small seeds might lead to both immediate and delayed consequences to E. umbelliflora fitness. Larger seeds can aggregate more reserve tissues that improve growing and vigour of seedlings, turning them into stronger survivors and competitors under distinct environmental adversities (Leishman et al. 2000, Alcántara \& Rey 2003, Pizo et al. 2006). Furthermore, they become more tolerant to shade, low soil moisture and nutrients, burial, and herbivory (Leishman et al. 2000).

Bustamante et al. (1992), in their study in Chile, concluded that, although foxes are legitimate seed dispersers, they are not efficient, since they deposit most of the seeds of Cryptocaria alba (Lauraceae) in open areas where mortality due to desiccation and predation is high. In our study, the deposition site and consequent plant recruitment was 
not evaluated, but crab-eating foxes are removing fruits that are not dispersed by birds. Thus, we suggest that the crab-eating foxes are reducing the density-dependent mortality beneath the parent tree. In addition, the decrease in germination time of the seeds consumed by the fox might have important consequences for E. umbelliflora early recruitment. The crab-eating fox may also play an important role in long distance dispersal of E. umbelliflora and in areas where large gape birds are rare or extinct.

\section{Acknowledgements}

We would like to thank FAPESP (Proc. 05/52726-9) for financial support. M. Galetti receives a research grant from CNPq and E. Cazetta from FAPESP (Proc. 03/08447-2). We also thank André C. Guaraldo for the pictures and the students of the ecology program at UNESP for their help in data collection.

\section{References}

ALCÁNTARA, J.M. \& REY, P.J. 2003. Conflicting selection pressures on seed size: evolutionary ecology of fruit size in a bird-dispersed tree, Olea europaea. J. Evolution. Biol. 16(6):1168-1176.

BERNARDI, J.V.E., LANDIM, P.M.B., BARRETO, C.L. \& MONTEIRO, R.C. 2005. Estudo espacial do gradiente de vegetação do Parque Estadual da Ilha do Cardoso, SP, Brasil. Holos Environ. 5(1):1-22.

BERTA, A. 1987. Origin, diversification, and zoogeograohy of south American canidae. Fieldiana, Zool. 39:455-471.

BISBAL, F.J. \& OJASTI, J. 1980. Nicho trofico del zorro Cerdocyoun thous (Mammalia, Carnivora). Acta Biol. Venez. 10(4):469-496.

BRADY, C. 1979. Observations on the behavior and ecology of the crab-eating fox (Cerdocyon thous). In Vertebrate Ecology in the northern Neotropics (J.F. Eisenberg, ed). Smithsonian Institution Press, Washington, DC, p. 161-171.

BUSTAMANTE, R.O., SIMONETTI, J.A. \& MELLA, J.E. 1992. Are foxes legitimate and efficient seed dispersers? A field test. Acta Oecol. 13(2):203-208.

CAMPOS, C.M. \& OJEDA, R.A. 1997. Dispersal and germination of Prosopis flexuosa (Fabaceae) seeds by desert mammals in Argentina. J. Arid Environ. 35(4): 707-714.

COIMBRA-FILHO, A.F. 1966. Notes on the reproduction and diet of azara's fox Cerdocyon thous azarae and the hoary fox Dusicyon vetulus at Rio de Janeiro Zoo. Int. zoo yearb. 6:168-169.

CÔRTES, M.C., CAZETTA, E., STTAGGEMEIER, V.G. \& GALETTI, M. 2009. Linking frugivore activity to early recruitment of a bird dispersed tree, Eugenia umbelliflora (Myrtaceae) in the Atlantic rainforest. Austral Ecol. 34(3):249-258.

DALPONTE, J.C. 1997. Diet of the hoary fox (Lycalopex vetulus), in Mato Grosso, Central Brazil. Mammalia, 61:537-546.

FACURE, K.G. \& GIARETTA, A.A. 1996. Food habits of carnivores in a coastal Atlantic Forest of southeastern Brazil. Mammalia, 60:499-502.

FACURE, K.G. \& MONTEIRO-FILHO, E.L.A. 1996. Feeding habits of the Crab-eating fox, Cerdocyon thous (Carnivora, Canidae) in a suburban area of southeastern Brazil. Mammalia, 60:147-149.
GATTI, A., BIANCHI, R., ROSA, C.R.X. \& MENDES, S.L. 2006. Diet of the crab-eating fox, Cerdocyon thous (Carnivora, Canidae) in Paulo Cesar Vinha Stat Park, Espírito Santo, State, Brazil. Mammalia, 70:153-155.

HERRERA, C.M. 1989. Frugivory and seed dispersal by carnivorous mammals, and associated fruit characteristics, in undisturbed mediterranean habitats. Oikos, 55:250-262.

JÁCOMO, A.T.A., SILVEIRA, L. \& DINIZ-FILHO, J.A.F. 2004. Niche separation between the maned wolf (Chrysocyon brachyurus), the crabeating fox (Dusicyon thous) and the hoary fox (Dusicyon vetulus) in central Brazil. J. Zool. Lond. 262:99-106.

LEISHMAN, M.R., WRIGHT, I.J., MOLES, A.T. \& WESTOBY, M. 2000. The evolutionary ecology of seed size. In Seeds: the ecology of regeneration in natural plant communities (M. Fenner, ed). Commonwealth Agricultural Bureau International, Wallingford, p. 31-57.

LINDSTEDT, S.L., MILLER, B.J. \& BUSKIRK, S.W. 1986. Home range, time, and body size in mammals. Ecology, 67(2):413-418.

MEDEL, R.G. \& JAKSIK, F.M. 1988. Ecología de los cánidos suramericanos: una revisión. Rev. Chil. Hist. Nat. 61:67-79.

MOTTA Jr., J.C., LOMBARDI, J. \& TALAMONI, S.A. 1994. Notes on crabeating fox (Dusicyon thous): seed dispersal and food habits in southeastern Brazil. Mammalia, 58:156-159.

NOFFS, M.S. \& BATISTA-NOFFS, L.J. 1982. Mapa da vegetação do Parque Estadual da Ilha do Cardoso: As principais formações. Silvicult. São Paulo, 16:620-628.

OLIVEIRA, E.M.C. 2006. Ecologia e conservação de mamíferos carnívoros de mata atlântica na região do complexo estuarino lagunar de cananéia, estado de São Paulo. Tese de Doutorado, Universidade de Campinas, Campinas.

OTANI, T. 2002. Seed dispersal by Japanese marten Martes melampus in the subalpine shrubland of northern Japan. Ecol. Res. 17:29-38.

PIZO, M.A., VON ALLMEN, C. \& MORELLATO, L.P.C. 2006. Seed size variation in the palm Euterpe edulis and the effects of seed predators on germination and seedling survival. Acta Oecol. 29(3):311-315.

REY, P.J., GUTIÉRREZ, J.E., ALCÁNTARA, J. \& VALERA, R. 1997. Fruit size in wild olives: implications for avian seed dispersal. Funct. Ecol. 11(5):611-618.

STAGGEMEIER, V.G., MORELLATO, L.P.C. \& GALETTI, M. 2007. Fenologia reprodutiva de Myrtaceae em uma ilha continental de Floresta Atlântica. Rev. Bras. Biosc. 5(S1):423-425.

TRABA, J., ARRIETA, S., HERRANZ, J. \& CLAMAGIRAND, M.C. 2006. Red fox (Vulpes vulpes L.) favor seed dispersal, germination and seedling survival of Mediterranean Hackberry (Celtis australis L.). Acta Oecol. 30(1):39-45.

WHEELWRIGHT, N.T. 1985. Fruit size, gape width, and the diets of fruiteating birds. Ecology, 63(3):808-818.

WILLSON, M.F. 1993. Mammals as seed-dispersal mutualists in North America. Oikos, 67:159-176. 